$<$ 症例報告 $>$

原発性肝内結石症に併存した肝内胆管癌の 1 切除例

一抗 BrdUモノクローナル抗体による

胆管上皮の細胞動態の検索一

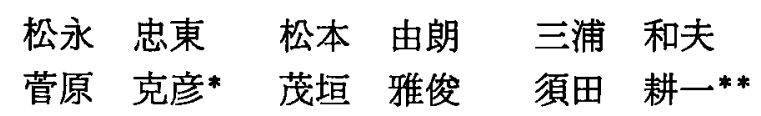

要 旨：右季肋部痛を主訴とする63歳女性でCT，USにより右葉肝内結石と診断した。 CA19$9 か ゙ 90 \mathrm{U} / \mathrm{m} l$ のため血管造影, 胆管造影を施行した。悪性腫暘の存在を示唆する画像所見は認め なかったが肝内胆管癌の併存を嶷い、開腹した。肝右葉は萎縮するも肝癌の存在は不明であった。 肝十二指腸間膜内リンパ節の迅速組織診で腺癌の転移の診断を得たので抁大肝右葉切除を施行 した。右葉胆管内に結石が充満し，前区域の払張胆管に直径 $1.2 \mathrm{~cm}$ の隆起性病変を認め中分化 型乳頭状腺癌であった。右肝静脈，右門脈，左肝管切離後右肝動脈上り術中に Bromodeoxyuridine (BrdU) 500mg 注入し，切除肝の胆管上皮を抗 BrdU モノクローナル抗体で染色し， $\mathrm{S}$ 期細胞を標識してその標識率（L.I.）を算出した。癌部の L.I. は8.6\%，癌近傍で非癌部胆管 上皮の L.I. は $8.8 \%$ であった. 一方肝門部の狭窄部胆管上皮は $0.5 \%$ ，さらに総肝管側の右肝管 は0.3\%と低值であり，結石を伴った肝内胆管上皮の細胞回転の亢進が示唆された。

索引用語： 原発性肝内結石症 肝内胆管癌 抗 BrdU モノクローナル抗体 胆管上皮の細胞動態

緒言

肝内結石症と肝内胆管癌の併存は癌の発生機序解明 の上からも最近注目されてきたが，報告例はまだ少な い. 最近, 著者らは術前の Carbohydrate antigen 199(CA19-9)の上昇と臨床経過のうえから肝内胆管癌の 併存を疑い開腹し，術中肝十二指腸間膜内リンパ節の 病理診断により癌の併存を確診して, 抎大肝右葉切除 術を施行し，さらに切除標本の Bromodeoxyuridine (BrdU) モノクローナル抗体を用いて胆管上皮の細胞 動態を検討し得た肝内結石症の 1 例を経験したので報 告する.

63歳, 女性.

主訴: 右季肋部痛.

既往歴：昭和39年胆石症のため胆信摘出術を施行さ れた。 昭和48年再び右季肋部痛出現して手術が施行さ れたが，詳細については不明である。

* 山梨医科大学第 1 外科

**同第 1 病理

＜受付日1988年11月 1 日 >
家族歴：特記することはない。

現病歴: 昭和63年 3 月下旬上り右季肋部痛が出現し たため近医を受診し入院となった。精査の結果, 肝内 結石と診断されて当科に紹介された。

現症：体格中等度, 栄養状態は普通で黄疸, 貧血は 認められず，上腹部正中および右肋弓下に手術湾痕を 認める法か，腹部触診上異常は認められなかった。

入院時検查所見 : ZTT, ALP, $\gamma$-GPT, LDH の軽 度上昇と ICG 15分值では軽度の排泄漣延を認めた。畽 場マーカーは, Carcinoembryonic antigen (CEA), Alpha-fetoprotein (AFP) は正常範围内であったか;, CA19-9は $90 \mathrm{U} / \mathrm{m} l$ と軽度の上昇を示した(Table 1). 超音波検查 (US) 所見：肝左葉は睡大して右葉は著し く荌縮していた，肝内胆管は前区域枝の壁の肥厚を認 め，その末梢に acoustic shadow を伴う strong echo を認めた。

Computed tomography (CT) 検査所見：肝右葉の 肝内胆管の拡張とその末梢の横隔膜直下の胆管の内部 に高吸収值の mass を有する低吸収域を認め, 経静脈 性造影剂により壁の一部が濃染された（Fig. 1a，b). 
$68: 574$

経皮経肝的胆道造影 (PTC) 所見：US ガイド下に, strong echoを有する酸状に拡張した右肝内胆管を穿 刺し造影した。穿刺時に胆汁は吸收されず，内部に結 石の存在を示唆する陰影欠損を認めた。また，左肝管 中枢側に胆管の狭窄を認めたが，外側区域の肝内胆管 には結石は認められなかった（Fig. 2a， b).

腹部血管造影所見：右肝動脈末梢枝に部分的に encasement を認め, 悪性病変の存在が示唆されたが, 結 石に伴ら炎症性変化との鑑別は困難であった（Fig. 3).

手術所見：昭和63年 5 月 31 日右肋弓下皮膚切開にて

Table 1 Laboratory data on admission.

\begin{tabular}{lc|cc}
\hline Peripheral Blood & S.Amy. & 210 Somogi U \\
RBC & $374 \times 10^{4} / \mathrm{mm}^{3}$ & Blood coagulation \\
Hb & $12.5 \mathrm{~g} / \mathrm{d} l$ & Prothrombin time \\
WBC & $4.4 \times 10^{3} / \mathrm{mm}^{3}$ & \multicolumn{2}{|c}{$14.2 \mathrm{sec}$} \\
Ht & $36.9 \%$ & \multicolumn{2}{|c}{$109.9 \%$} \\
Plt & $13.2 \times 10^{4} / \mathrm{mm}^{3}$ & Fibrinogen \\
Biochemistry & & \multicolumn{2}{|c}{$349.4 \mathrm{mg} / \mathrm{d} l$} \\
T.Bil & $0.6 \mathrm{mg} / \mathrm{d} l$ & Ch-E & $1.37 \Delta \mathrm{pH}$ \\
D.Bil & $0.2 \mathrm{mg} / \mathrm{d} l$ & TTT & $12.3 \mathrm{KU}$ \\
GOT & $31 \mathrm{U} / l$ & ZTT & $11.0 \mathrm{KU}$ \\
GPT & $23 \mathrm{U} / l$ & Serological tests \\
LDH & $370 \mathrm{U} / l$ & CEA(RIA) & $1.44 \mathrm{ng} / \mathrm{m} l$ \\
ALP & $198 \mathrm{U} / l$ & AFP(RIA) & $4.52 \mathrm{ng} / \mathrm{m} l$ \\
LAP & $53 \mathrm{U} / l$ & CA19-9(RIA) \\
$\gamma \cdot$ GTP & $51 \mathrm{U} / l$ & \multicolumn{2}{|c}{$90.41 \mathrm{U} / \mathrm{m} l$} \\
T.P. & $7.3 \mathrm{~g} / \mathrm{d} l$ & HBsAg & $(-)$ \\
T.Chol. & $176 \mathrm{mg} / \mathrm{d} l$ & ICG(15min) & $12.0 \%$ \\
\hline \multicolumn{2}{l}{}
\end{tabular}

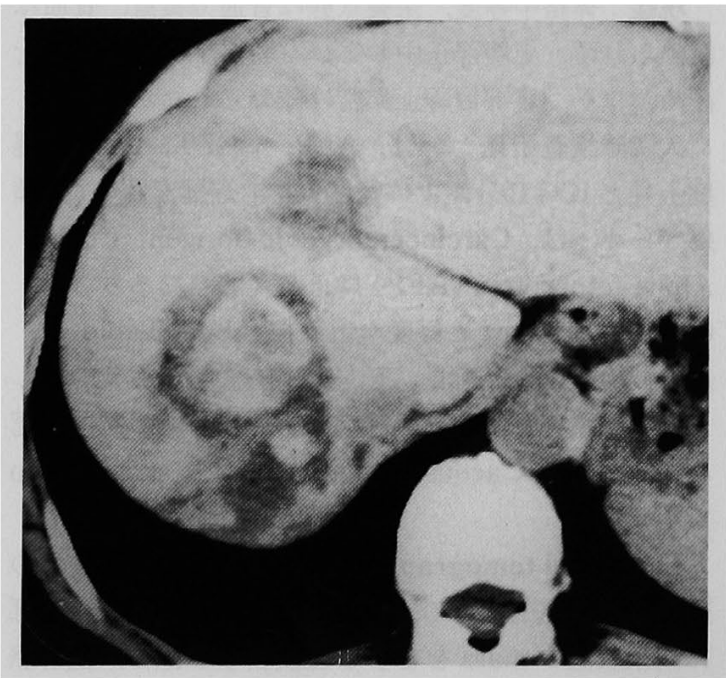

a

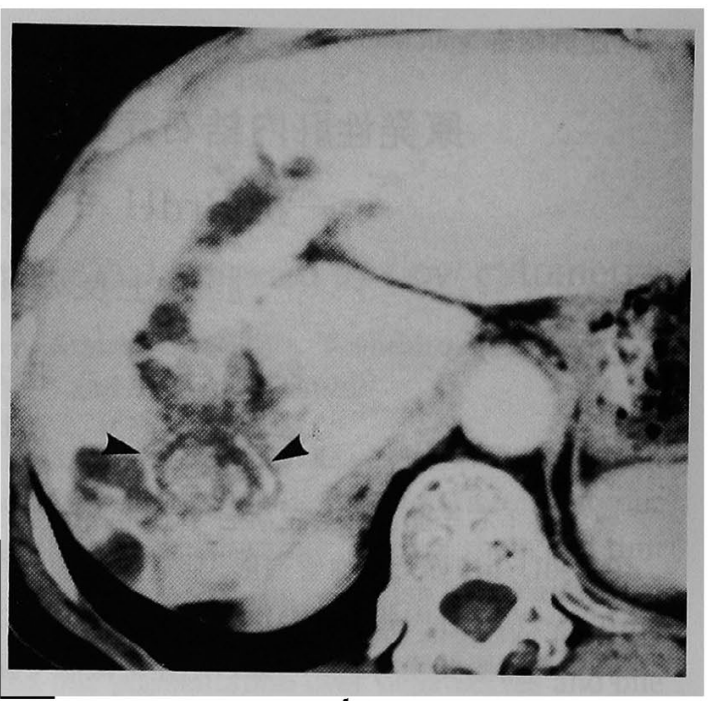

b

Fig. 1 CT scan

a) CT shows high density mass in the low density area of the right hepatic lobe. b) Contrast enhanced scan at the same level shows thickened wall of the bile duct (arrow heads).

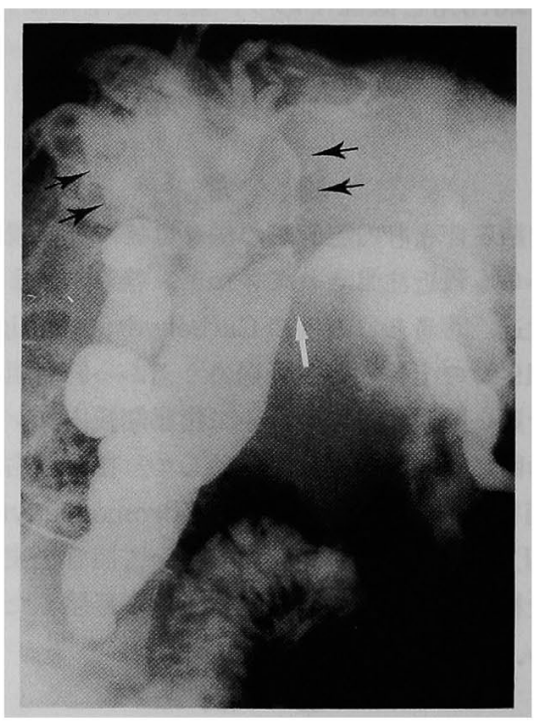

Fig. 2 PTC. PTC shows gallstones impacted in the intrahepatic bile ducts of the right lobe (arrow). The biliary stricture is demonstrated at the root of the left hepatic duct (white arrow).

開腹した，肝右葉は萎縮し，肝表面には多数の白色栗 粒大結節が認められ，日本住血吸虫症による肝䁍の変 化と考えられた。術中超音波検查では，肝右葉内に多 


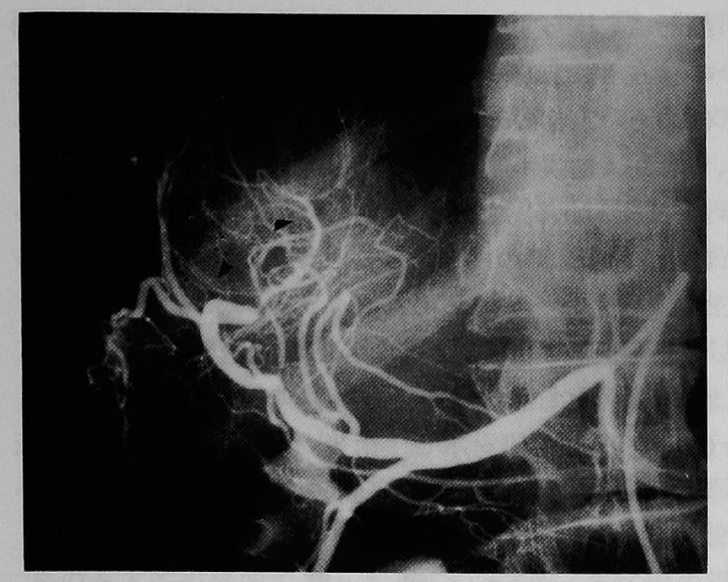

Fig. 3 Midarterial phase of the hepatic arteriogram. The branches of the right hepatic artery are displaced around a hypovascular area (arrow heads) and have irregular walls.

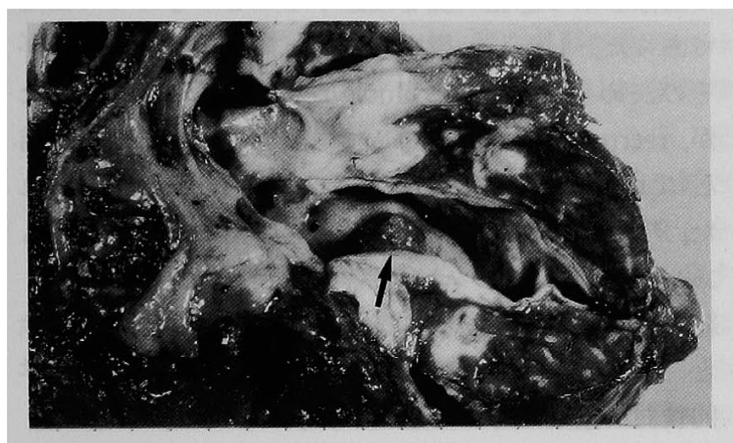

Fig. 4 Macroscopic findings of the speciemen. Surgical specimen shows dilated intrahepatic bile ducts impacted bilirubin calcium stones and after removal of stones an elevated lesion in the wall was revealed (arrow).

数の strong echo を認めたが, 悪性腫湟の存在を示唆 する所見は得られなかった。肝十二指腸間膜内リンパ 節 $\left(\mathrm{No}^{2} 12 \mathrm{a}_{2}\right)^{8)}$ の腫脹を認め, 術中迅速組織診断にて, adenocarcinoma の存在が確認されたために, 術前の 検查成績と術中所見から肝右葉肝内結石に併存する肝 内胆管癌の診断で拡大肝右葉切除術, 肝十二指腸間膜 内の胆管切除とリンパ節樀清 (No. 8a，p，9，12，13 $\mathrm{a}, 14 \mathrm{a}, \mathrm{b})^{8)}$, 胆道再建術が施行された。

切除標本所見：右肝内胆管は执張し，内部に黒色の ビリルビンカルシウム石が充満しており，胆管壁は肥 厚して同領域の肝実質は白色を帯び線維化が認められ た．前区域と思われる肝内胆管の壁の一部に径 $1.2 \mathrm{~cm}$

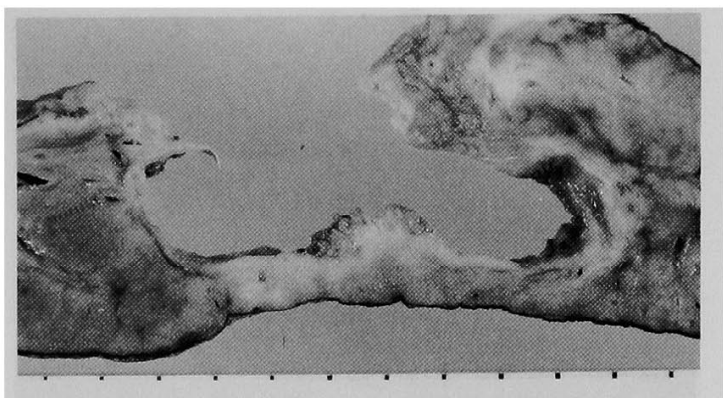

Fig. 5 Cut surface of the specimen. An elevated lesion is demonstrated in the dilated intrahepatic bile duct with wall thickness and shows papillary projection.

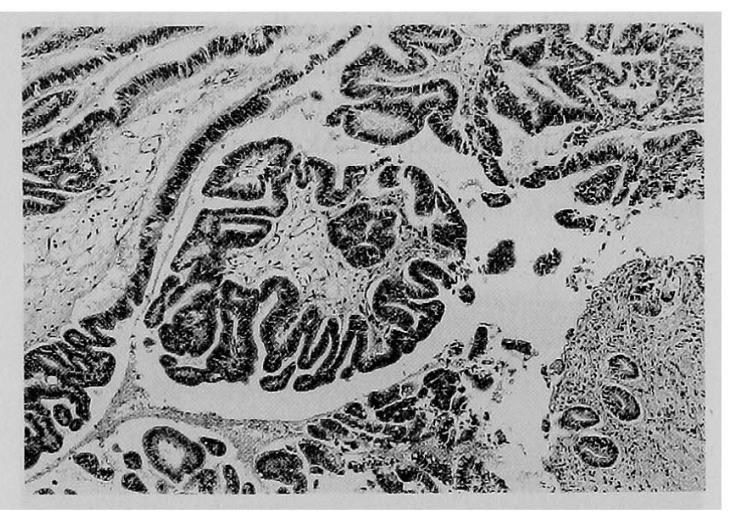

Fig. 6 Microscopic findings of the elevated lesion of the intrahepatic bile duct. Papillary lesion shows moderately differentiated adenocarcinoma (H.E. stain, $\times 25)$.

の隆起性病变を認めた (Fig. 4)。同部の割面では乳頭 状增殖が認められ，その基底部胆管は白色で壁肥厚が 著しく, 癌の浸潤性進展が示唆された (Fig. 5).

肝切除の過程で右肝静脈，閃脈右枝をそれぞれ起始 部で結禁切離し, 左肝管を肝実質近くで切離した後, 右肝動脈内に BrdU 500mg を注入して肝切除を完了 した，切除標本をアルコール固定後，右肝内胆管拡張 部，胆管の相対的狭窄部，右肝管の 3 力所を中心に胆 管上皮の病理組織学的検索之抗 BrdU モノクローナ ル抗体標識率 (以下 labeling index : L.I.) 算出した。 L.I.は1,000個以上の胆管上皮細胞を算出乙て，その中 に含まれる標識細胞の割合を\%で表わした。

乳頭状増殖部は胞体が eosinophilic で核のクロマチ ンに富んだ細胞よりなる中分化型乳頭状腺癌であり， 部分的に goblet cell を認め, 増生した胆管壁内の胆管 


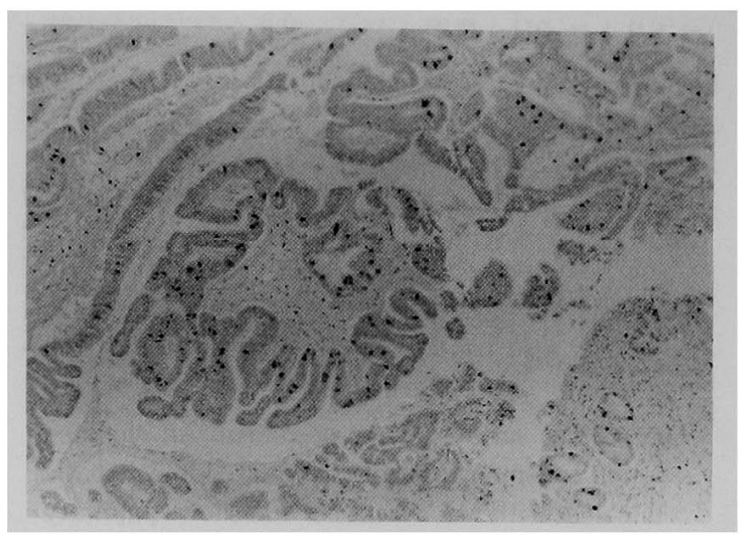

Fig. 7 Papillary adenocarcinoma in the wall of the intrahepatic bile duct with gallstones impacted. BrdU-positive cells are irregularly scattered throughout pseudoglandular structures (Immunohistochemical staining with anti-BrdU monoclonal antibody : weak counterstain with $H$. E. $\times 25$ ).

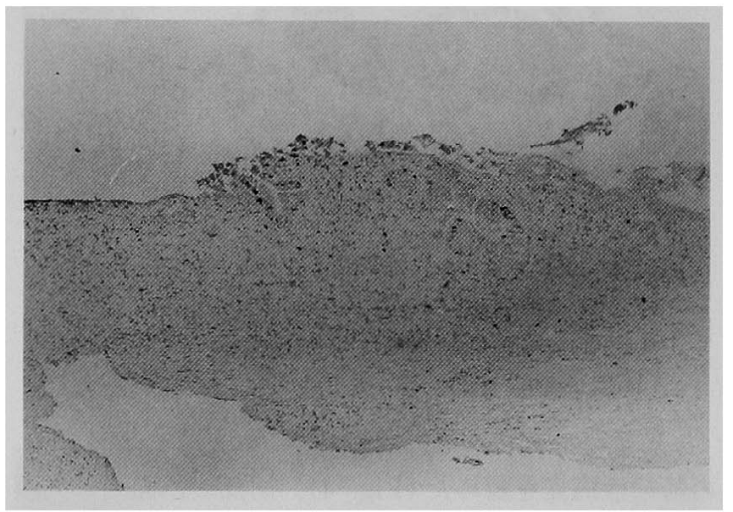

Fig. 8 Immunohistochemical staining with antiBrdU monoclonal antibody of proliferation of the glandular elements in the wall of the intrahepatic bile duct with stones impacted. Numerous BrdUpositive cells are identifiable in correspondence with nuclear stratification and epitherial cribriform pattern. (weak counterstain with H.E. stain, $\times 25$ ).

腺（壁内腺）にも癌の浸潤が認められた（Fig. 6).癌 部の L.I. は8.6\%であった（Fig. 7).

一方，結石の充満した部分の胆管上皮は非癌部では ほとんど剝脱しているが，一部では増生した壁内腺の 円柱上皮細胞が抗 BrdU モノクローナル抗体で高率 に標識された（Fig. 8). 同部の胆管上皮の標識率は非
癌部にも拘らず, $8.8 \%$ と癌部より高い値を示した。癌 の存在した拡張部胆管より肝門側の相対的狭窄部位 は，その末梢の結石充満部に比べて胆管上皮は保たれ ており，粘膜下結合織の増生之壁内腺の増殖を認める が，L.I.は0.5\%と低值であった。また，それよりさら に十二指腸側の右肝管の上皮の L.I.は0.3\%であっ た.

術後経過：昭和63年 7 月13日軽快退院し，外来にて 経過観察中である。術後 6 カ月の経過中にはCEA, CA19-9は正常值を示し, 術後のCT, USでも訮内転 移, リンパ節転移の所見は認めず家庭生活を送ってい る.

\section{考察}

肝内結石と胆管癌の併存は，その成因上からす関心 がもたれ，また術前診断上多くの課題を提供している. 本症例では術前に悪性病変の併存が疑われたが, 術前 の画像診断で悪性病変を確診することはきわめて困難 であった、しかし，術中のリンバ節の迅速病理診断が その決め手となり en block resectionが施行できた が, retrospective に検討してす䏣管癌による所見を結 石による炎症性変化と鑑別することは至難と思われ た、PTC および吸引細胞診が有用であるという報告す あるが3,7,9,10)，それも確実性がなく ${ }^{11)}$, 本症例のごとく 結石が限局している昜合には，積極的に広範な肝切除 と術中の局所所見に応じて段階的に行なわれる組織学 的検討が重要であると思われた。

肝内結石症に併存する肝内胆管癌の発生機序として は，従来より結石による機械的刺激，おょび長期間の 胆汁 $っ っ$ 滞之胆道感染の反復が胆管上皮の過形成変化 をひきたここのことが発癌の前駆病変と考えられ ている2 . 本症例においては, 癌の発生母地が結石の 充満した拡張胆管であり, 明らかな乳頭状増殖を呈し さらに周囲に浸潤性に増殖していることから，胆管上 皮の剝離, 再生が同部の上皮の乳頭状增生を促し, 胆 管癌の発生をもたらしたことが濃厚に推定される。そ の根拠として癌部以外にも増生した壁内腺の一部に乳 頭状発育を呈する部分が観察されている.

BrdUはDNAを構成する thymidine の analogue であり，細胞が DNA 合成期（S 期）にある場合には DNA 内に取り迅まれる。この標識細胞を抗 BrdUモ ノクローナル抗体 ${ }^{12)}$ を作用させて免疫組織学的に同定 する方法は ${ }^{13,14)}$ ，すでに脳腫瘍の成長解析に利用され ている(15).

野口は胆变上皮の細胞動態を比較検討し, 正常胆萃 
粘膜上皮の L.I. は平均 $0.3 \%$ であのに対し膵・胆管 合流異常を伴う胆囊癌の癌部の L.I. は平均 $8.5 \%$, 打 よび同非癌部では平均 $3.3 \%$ 之報告した ${ }^{16)}$. 本症例で は，右肝内胆管の相対的狭窄部の L.I.は0.5\%であり， さらにそれより十二指腸側の胆管上皮では $0.3 \%$ とほ ぼ正常胆覆粘膜の L.I.に近似していた。しかし，結石 の充満した拡張胆管の癌近傍非癌部の一部では, 増生 した壁内腺の上皮細胞に著しい異型性を認め, BrdU 標識細胞が極めて高率に存在し，その L.I.は8.8\%と 癌部の $8.6 \%$ りむむしろ高値を示している.中沼ら は，慢性增殖性胆管炎にみられる異型胆管上皮の過形 成が胆管癌の前駆病変で, 壁内腺の増生は増殖性胆管 炎の基本的組織像であるとしているが5)，本症例に認 められた拡張胆管部の L.I.の高值は同部において細 胞回転が異常に元進していることを示唆して抢り， cell kinetics の点からも胆管上皮の過形成が発癌へつ ながる可能性を示唆するものである.

肝内結石症の治療に関しては，現在外科的切除の注 かに内視鏡的切石術，レーザーによる切石之胆管狭窄 の解除などによる集学的治療が展開されている17). 松 本らは肝内胆管の推張と肝門部胆管の狭窄を持つ肝内 結石症は先天性胆管形成異常がその背景にあることを 報告し ${ }^{18)}$ ，狭窄胆管の領域肝実質はいずれ荒砗萎縮す る運命にあるところから肝切除を主張してきた

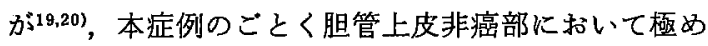
て高い細胞回転の亢進を認めたことは, その問題に加 えて, 肝内結石に併存する胆管上皮の悪性化の potency が高いことを示唆しており，治療方針決定の うえで重要な問題を提起するるのである。

したがって長期にわたる原発性肝内結石症は臨床症 状の有無にかかわらず肝切除の対象となるととるに, 切除に際しては悪性病変の存在を念頭において腫瘍存 在区域の en block resection と領域リンパ節廓清を併 施した治痹切除術式を採用すべきであることを本症例 から強調したい。

\section{結 語}

抗 BrdU モノクローナル抗体を用いて胆管上皮の 細胞動態を検討し得た原発性肝内結石症に併存した肝 内胆管癌の 1 例を報告した。本症例では拡張胆管の非 癌部上皮に括いて細胞回転の充進を認め，原発性肝内 結石症に打ける胆管上皮の悪性化への potency が示 唆された。この細胞動態は原発性肝内結石症の治療方 針決定に際して採択されるべき重要な因子になるもの と思われる。
文献

1) Sanes S, MacCallum JD: Primary carcinoma of the liver: Cholangioma in hepatolithiasis. Am J Pathol 18: 675-683, 1942

2) Falchuk KR, Lesser PB, Galdabini JJ, et al: Cholangiocarcinoma as related to chronic intrahepatic cholangitis and hepatolithiasis. Am J Gastroenterol 66:57-61, 1976

3）山本賢輔, 土屋凉一, 伊藤敏哉, 他：肝内結石症之 肝内胆肝癌の合併例の検討. 日消外会誌 17(3): $601-609,1984$

4）太田哲生, 永川宅和, 小西一朗, 他：肝内結石症の 病理組織学的検討一特に前癌病変について一. 肝・胆 - 膵 $9(1): 123-129,1984$

5) Nakanuma $Y$, Terada $T$, Tanaka $Y$ : Are hepatolithiasis and cholangiocarcinoma aetiologically related ?-A morphological study of 12 cases of hepatolithiasis associated with cholangiocarcinoma. Virchows Arch [Pothol Anat] 406: 45-58, 1985

6) Koga A, Ichimiya $H, Y$ amaguchi $K$, et al : Hepatolithiasis associated with cholangiocarcinoma-Possible etiologic significance. Cancer $55: 2826-2829,1985$

7）太田哲生, 永川宅和, 小西一郎, 他：䀒内結石症に 合併した肝内胆管癌 7 例之肝内胆管腺腫 1 例の臨 床病理学的検討. 日消外会誌 $20: 748-753,1987$

8）日本肝癌研究会：原発性肝癌取扱い規約. 金原出 版, 東京, 第 2 版, 1987

9）品川 孝, 磯村伸治, 広田勝太郎, 他：術前に診断 乙得た肝内胆石合併肝内胆管癌の 1 例. 日消誌 81(7) : 1642-1646, 1984

10) Radin DR, Ray MJ, Ralls PW, et al: Hepatolithiasis complicated by cholangiocarcinoma. J Comput Tomogr 11 : 315-317, 1987.

11）長谷川洋, 二村雄次, 早川直和, 他 : 術前診断に難 渋した肝内結石症に合併した胆管細胞癌の 1 例. 胆と膵 5(11): 1581-1585, 1984

12) Gratzner HG: Monoclonal antibody to 5bromo-and 5-iododeoxyuridine: A new reagent for detection of DNA replication. Science 218 : $474-475,1982$

13) Dolbeare F, Gratzner H, Pallavicini MG, et al : Flowcytometric measurement of total DNA content and incorporated bromodeoxyuridine. Proc Natl Acad Sci 80 : 5573-5577, 1983 
14) Morstyn G, Hsu SM, Kinsella $T$, et al: Bromodeoxyuridine in tumor and chromosomes detected with a monoclonal antibody. J Clin Invest $72: 1844-1850,1983$

15）長島 正，星野孝夫：脳尰湟成長解析のあゆみと 展望一特に Bromodeoxyuridine 単一クローン抗 体による迅速解析法について. 脳神外科 12 ： $1007-1018,1984$

16）野口明宏：膵・胆管合流異常症例における胆道上 皮の細胞動態一Bromodeoxyuridine (BrdU) モ) クローナル抗体を利用した解析。日消外会誌 21(2) : 210-220, 1988
17）中山文夫：肝内結石症の治療方針．外科治療 28(11) : 1393-1397, 1986

18) Matsumoto $Y$, Fujii $H$, Sugahara $K$, et al : Strictures as a cause of primary intrahepatic bile duct stones. World J Surg 10: 867-875, 1986

19）松本由朗：胆道の形成異常とその臨床. 日消外会 誌 $19: 614-623,1986$

20）和田敏末：原発珄肝内結石症における胆管狭窄の 臨床的意義一切除肝の䠰床病理学的研究. 日消外 会誌 $18: 2305-2313,1985$

\title{
A resected case of cholangiocellular carcinoma with primary intrahepatic bile duct stones: Immunohistochemical study of epitherial cell proliferation in the intrahepatic bile ducts
}

\author{
Tadaharu Matsunaga Yoshiro Matsumoto, Kazuo Miura, Katsuhiko Sugahara, \\ Masatoshi MogaKI and Kohichi SUDA*
}

A 63-year-old female was admitted to our hospital due to right hypochondralgia in May 1988. Laboratory data showed slight dysfunction of liver function test with $90 \mathrm{U} / \mathrm{ml}$ of CA19-9. Imaging studies of CT, US and direct cholangiogram revealed impacted intrahepatic bile duct stones in the right lobe but no malignant tumor was detected in the liver.

Intraoperative histological examination of the frozen section of a lymph node in the hepatoduodenal ligament indicated the metastatic adenocarcinoma. Extended hepatic lobectomy with dissection of the regional lymph nodes was performed. An elevated lesion was revealed after removal of stones in the dilated duct wall in the anterior segment and histological study showed moderately differentiated papillary adenocarcinoma of the intrahepatic bile duct. Immunohistochemical study using a monoclonal antibody to bromodeoxyuridine showed $8.6 \%$ of labeling index in the elevated lesion and $8.8 \%$ in the non-cancerous epithelia of its neighbouring duct wall, and $0.5 \%$ in the wall of the narrowed bile duct in the hilum and $0.3 \%$ in the right hepatic duct.

\footnotetext{
* Department of Surgery, Department of Pathology, Yamanashi Medical College (Yamanashi)
} 